\title{
Point of care diagnostics and non-invasive sampling strategy: a review on major advances in veterinary diagnostics
}

\author{
Mousumi Bora ${ }^{1}$, Manu $\mathrm{M}^{1}$, Dayamon D. Mathew ${ }^{1}$, Himasri Das ${ }^{2}$, \\ Durlav Prasad Bora ${ }^{2}$, Nagendra Nath Barman ${ }^{2}$
}

${ }^{1}$ Banaras Hindu University, Faculty of Veterinary and Animal Sciences, Mirzapur, Uttar Pradesh, India ${ }^{2}$ Assam Agricultural University, College of Veterinary Science, Guwahati, Assam, India

Received May 17, 2021

Accepted October 11, 2021

\begin{abstract}
The use of point of care diagnostics (POCD) in animal diseases has steadily increased over the years since its introduction. Its potential application to diagnose infectious diseases in remote and resource limited settings have made it an ideal diagnostic in animal disease diagnosis and surveillance. The rapid increase in incidence of emerging infectious diseases requires urgent attention where POCD could be indispensable tools for immediate detection and early warning of a potential pathogen. The advantages of being rapid, easily affordable and the ability to diagnose an infectious disease on spot has driven an intense effort to refine and build on the existing technologies to generate advanced POCD with incremental improvements in analytical performance to diagnose a broad spectrum of animal diseases. The rural communities in developing countries are invariably affected by the burden of infectious animal diseases due to limited access to diagnostics and animal health personnel. Besides, the alarming trend of emerging and transboundary diseases with pathogen spill-overs at livestock-wildlife interfaces has been identified as a threat to the domestic population and wildlife conservation. Under such circumstances, POCD coupled with non-invasive sampling techniques could be successfully deployed at field level without the use of sophisticated laboratory infrastructures. This review illustrates the current and prospective POCD for existing and emerging animal diseases, the status of non-invasive sampling strategies for animal diseases, and the tremendous potential of POCD to uplift the status of global animal health care.
\end{abstract}

Animal diseases, surveillance, field diagnosis, resource-limited settings

The incidence of emerging infectious diseases has increased in the recent decades and threatens to increase in the near future (Dikid et al. 2013). Pathogenic microorganisms have been expanding their population through evolutionary rescue by natural selection, a feature which is an interplay between co-evolutionary dynamics of hosts, pathogens, and environment (Gandon et al. 2013). The recurrent and widespread feature of evolutionary rescue of microorganisms emphasizes a broader term called 'emerging pathogens', which are increasing their fitness rapidly enough to prevent their extinction (Gandon et al. 2013). Besides genetic mutations and evolution of microorganisms, the major drivers of emerging diseases in human and animal populations can be human and environmental factors, such as (i) deforestation and associated biodiversity loss, (ii) imbalances in agricultural and food supply systems, (iii) increase in travel, trade, and traffic, (iv) persistence of poor health systems and protection practices and climate change (Engering et al. 2013). Since the $1940 \mathrm{~s}$, agricultural drivers were found to be associated with $>25 \%$ of all and $>50 \%$ of zoonotic infectious diseases that have emerged in humans through both wild and domestic animals (Rohr et al. 2019). Therefore, control and prevention of emerging and existing diseases of domestic and wildlife population is of paramount importance in order 
to avert the devastating effects on animal health and production, nutritional security and public health (McElwain and Thumbi 2017).

Animal health surveillance is an effective tool to monitor disease trends, for control measures and to provide data for use in risk analysis for animal and public health purposes (OIE 2019a). Therefore, epidemiology and laboratory networks play an important role in gathering data to understand disease dynamics and to provide an epidemiological interpretation of a defined disease (FAO 2011). Accuracy of disease diagnosis depends on the availability of an appropriate sample collected in a timely manner and transported under suitable conditions (Balogh et al. 2015). In most situations, maximum recovery of microbial pathogens is often not achieved due to inappropriate sample collection, transport and storage (Gilor and Gilor 2011). Collection and transportation of biological samples from animals is difficult especially in developing countries with limited resource settings as well as in regions where diagnostic laboratories are scarcely distributed. Besides, collecting biological samples from domestic, captive, and wild animals using invasive techniques requires skilled handler or restrainer which is not always feasible due to lack of skilled manpower (Zemanova 2019) or not allowed in wild fauna. In such situations, non-invasive techniques of sample collection and point-of-care diagnostics (POCD) are ideal components of animal disease diagnosis (Howson et al. 2017). Easy to use POCD format can be successfully deployed at field level and primary veterinary dispensaries without the use of sophisticated laboratory infrastructures. In this review, we will discuss the current status and future perspectives of POCD techniques in detection of animal diseases. Further, we will discuss the non-invasive sampling strategies in veterinary medicine and its importance in wildlife research.

\section{Animal diseases of the past, present and future}

We have all learnt about the importance of infectious diseases of animals, including rinderpest (cattle plague), the first animal disease to be eradicated globally in 2011 . Eradication of rinderpest, the devastating disease of livestock responsible for world-wide famine and poverty was one of the greatest achievements in veterinary sciences (Roeder et al. 2013). With the establishment of Global Rinderpest Eradication Programme in 1994 by the World Organization for Animal Health (OIE) and Food and Agricultural Organization of the United Nations (FAO), the challenge of rinderpest eradication started with a time bound deadline established for its completion by the year 2010. The commercial production of the Plowright tissue culture rinderpest vaccine developed in 1960 (Plowright and Ferris 1962) and availability of effective diagnostics (indirect and competitive ELISA format) (Anderson et al. 1990) for detecting rinderpest antibodies to confirm diagnosis and monitor the effectiveness of vaccination programmes were the mainstay which led to the eradication of rinderpest (FAO 2012).

Since the eradication of rinderpest, the FAO and the OIE have been focusing on the global control of another devastating disease of small ruminants, peste-des-petits ruminants (PPR), with a goal of its eradication by the year 2030 (FAO and OIE 2015). Besides, keeping in view of the global economic consequences due to recent increase in epidemics of transboundary animal diseases such as foot and mouth disease (FMD) and African swine fever (ASF), the FAO and the OIE have launched global control strategies to implement the measures on preparedness, prevention, detection and control of both the diseases (FAO and OIE 2020). Among the OIE-listed livestock diseases, a sharp rise in the number of emerging diseases has been witnessed in the recent decade. Some of the examples include lumpy skin disease (LSD) (Tasioudi et al. 2016; Sudhakar et al. 2020), Rift Valley fever (RVF) (Gaudreault et al. 2019; Lag are et al. 2019), porcine reproductive and respiratory syndrome (PRRS) (Rajkhowa et al. 2015; Zhang et al. 2019), camel pox infections 
(Al-Zi'abi et al. 2007; Erster et al. 2018) and equine coronavirus infections (Pusterla et al. 2016; Nemoto et al. 2019). Several other diseases of livestock that have re-emerged in the recent years due to the changing incidence of pathogens and patterns of diseases over time include blue tongue (BT) (Purse et al. 2005; Sailleau et al. 2017), African horse sickness (AHS) (Maclachlan and Guthrie 2010; Thompson et al. 2012), West Nile fever (WNF) (Schvartz et al. 2020) and anthrax (Kisaakye et al. 2018; Stella et al. 2020). Bearing in mind the recent patterns of evolving novel pathogens and emerging diseases such as influenza, Nipah, Middle East respiratory syndrome (MERS) and most recently coronavirus disease (COVID-19) in animals, constant awareness and pursuance of effective strategies for controlling infectious diseases and disease emergence thus remain crucial. The unpredictable nature of evolving pathogens requires immediate attention from clinical microbiologist and infectious disease experts to stimulate research on emerging infections including surveillance and diagnostics.

\section{Progress in animal disease surveillance by use of POCD}

The development of simple, rapid, and portable diagnostic devices is now considered a priority for animal diseases. In the recent years, tremendous advances in POCD have been witnessed, which are a result of continuous developments in biosensors, microfluidic, bioanalytical platforms, assay formats, lab-on-a-chip technologies and complementary technologies (Vashist 2017). This section describes the current status of POCD focusing on antigen/antibody and nucleic acid detection technologies for on-spot detection of animal diseases and their future utilization as complementary to conventional laboratory techniques.

\section{Antigen/antibody detection systems}

\section{Lateral flow device (LFD)}

Detection of antigens can be done using portable immunochromatographic strips, also known as antigen-lateral flow device (Ag-LFD), which works by binding both antigen and antibody-coated detector particles to bands of capturing monoclonal antibody (mAb) on various zones of a polymeric strip through capillary action (Howson et al. 2017). The lateral flow technology was derived from latex agglutination test developed by Singer and Plotz in 1956 (Singer and Plotz 1956). A lateral flow test strip consists of four overlapping membranes, sample pad, conjugate pad, nitrocellulose membrane and absorbent pad (Sharma et al. 2015). The typical configuration of an immunochromatographic strip and its mechanism of action are illustrated in Fig. 1 (Plate III). As shown in the figure, the sample containing the target antigen/analyte or biomarker is applied on the sample pad, which is impregnated with buffer salts and surfactants that make the sample suitable for interaction with the detection system. The treated sample migrates through the conjugate pad, which contains antibodies specific to the target agent and are conjugated to coloured or fluorescent particles (colloidal gold/latex microspheres/carbon nanotubes) (Koczula and Gallotta 2016). The conjugated antibody bound to the target antigen migrates along the strip into the detection zone which is a porous membrane usually composed of nitrocellulose, where the antigen-conjugated antibody complex is trapped by the immobilized capture antibody in the test line forming a coloured reaction indicating the presence of the antigen of interest. The excess conjugated antibody will be captured at the control zone by secondary antibody which is indicative of proper flow of the sample through the strip (Sajid et al. 2015; Koczula and Gallotta 2016). The absorbent pad maintains the flow rate of the buffer over the membrane and stops back flow of the sample. LFD is available in three formats, (i) sandwich, (ii) competitive, and (iii) multiplex detection format (Sajid 
et al. 2015). LFDs are rapid (display results within 5-30 min), user-friendly, inexpensive and disposable which makes them an ideal device of disease detection under low resource settings (Koczula and Gallotta 2016). Since its introduction, the technology and its applications have been used in several human diseases (Sharma et al. 2015). The OIE have now recommended the use of LFD for rapid detection of high impact livestock diseases such as FMD (OIE 2019b) and PPR (OIE 2019c). A comprehensive list of Ag-LFDs developed for detection of OIE listed diseases have been tabulated (Table 1). In addition, with the developments in reader technology and advancements in raw materials, such as labels, LFD can match the sensitivity of enzyme linked immunosorbent assay (ELISA), and might be a substitute to ELISA in sero-epidemiology of animal diseases in near future.

Table 1. Overview of antigen-LFDs developed for detection of OIE listed livestock diseases.

\begin{tabular}{|c|c|c|c|}
\hline Animal disease & Agent & $\begin{array}{l}\text { mAb target against } \\
\text { (Protein/Whole purified antigen) }\end{array}$ & References \\
\hline Foot-and-mouth disease & FMDV & $\begin{array}{l}\text { FMDV type SAT } 2 \text { whole viral antigen } \\
\text { FMDV types } O, A, C \text {, and Asia } 1 \text { whole viral antigen }\end{array}$ & $\begin{array}{l}\text { Oem et al. } 2009 \\
\text { Ferris et al. } 2010\end{array}$ \\
\hline Peste-des-petits- ruminants & PPRV & PPRV-Haemagglutinin protein & Baron et al. 2014 \\
\hline African swine fever & ASFV & ASFV-VP 72 protein & Sastre et al. 2016 \\
\hline Classical swine fever & CSFV & CSFV-whole viral antigen & Sambandam et al. 2017 \\
\hline Vesicular stomatitis & VSV & VSV-glycoprotein: Indiana (subtype 1) and New Jersey & Ferris et al. 2012 \\
\hline Bovine viral diarrhoea & BVDV & BVDV-Erns protein & $\begin{array}{l}\text { IDEXX Laboratories, } \\
\text { Inc., Westbrook, Maine, USA }\end{array}$ \\
\hline Bovine tuberculosis & M. bovis & Irradiated $M$. bovis $\mathrm{AF} 2122 / 97$ & Stewart et al. 2017 \\
\hline Anthrax & B. anthracis & B. anthracis capsular polypeptide (Polyglutamic acid) & Kolton et al. 2019 \\
\hline Rift Valley fever & RVFV & RVFV-Nucleoprotein & Cêtre-Sossah et al. 2019 \\
\hline West Nile fever & WNV & WNV-Envelope glycoprotein & Rebollo et al. 2018 \\
\hline Rabies & RABV & RABV-Nucleoprotein & Kang et al. 2007 \\
\hline
\end{tabular}

mAb - monoclonal antibody; FMDV - Foot-and-mouth disease virus; PPRV - Peste-des-petits-ruminants virus; ASFV - African swine fever virus; CSFV - Classical swine fever virus; VSV - Vesicular stomatitis virus; BVDV - Bovine viral diarrhoea virus; PRRSV - Porcine reproductive and respiratory syndrome virus; M. bovis - Mycobacterium bovis; B. anthracis - Bacillus anthracis; RVFV - Rift Valley fever virus; WNF - West Nile fever virus; RABV - Rabies virus

\section{Dipstick assay}

The dipstick assay is a rapid immunochromatographic assay, which is a simplified version of LFD. In dipstick assay, the sample pad and the conjugate pad are substituted by a solution into which the nitrocellulose membrane is immersed (de Puig et al. 2017). The nitrocellulose strip bearing immobilized antibodies is put in contact with a solution containing the running buffer, biological sample and antibody conjugated to coloured or fluorescent particles, mostly colloidal gold (Plate III, Fig. 2). Dipstick assay eliminates the need to dry down the conjugated antibody. Dipstick assay is now gaining popularity as POCD as it is applicable in almost every environment from field to clinical settings. The dipstick technology has been developed to detect different animal diseases such as canine leishmaniasis (Schallig et al. 2004), bovine tuberculosis (Mosaad et al. 2012), and bovine brucellosis (Poonati et al. 2020).

\section{Immunocomb assay}

The immunocomb assay is a highly sensitive simplified form of ELISA which can be described as an enzyme labelled 'dot assay' that detects antibody levels in serum or 
whole blood. The immunocomb assay is available in a kit format with all the necessary reagents to develop the test without the need of sophisticated equipment for classic ELISA like special dispensers, automatic washer or electronic reader. Immunocomb kits contain two main components: a comb shaped plastic card, referred to as the comb and a multi compartment developing plate (Plate IV, Fig. 3). Each comb has 12 teeth, activated with specific antigens localized to dots on the comb, which may be used individually or any number up to 10 , by breaking off the desired number of teeth from the comb and using the corresponding column of wells in the developing plate (Biogal Galed Labs 2015). The assay can be performed at room temperature $\left(20-25^{\circ} \mathrm{C}\right)$ within a simple clinical setting or veterinary dispensary and provides results within $20-60 \mathrm{~min}$. The reaction time may vary according to antigens and antigen/antibody reactions. The level of antibodies (antibody titres to a particular antigen) is determined according to the intensity of the test colour developed which can be interpreted by naked eye or with a comb scale provided with the kit. Commercial immunocomb assay kits are currently available for detection of bovine (brucellosis and leptospirosis), canine (parvovirus infections, canine distemper, brucellosis, ehrlichiosis and leptospirosis) and feline diseases (feline infectious peritonitis).

\section{Nucleic acid-based detection systems}

Recombinase polymerase amplification-lateral flow dipstick (RPA-LFD) assay

Recombinase polymerase amplification (RPA) is a highly sensitive and selective isothermal amplification technique that can operate at $37-42{ }^{\circ} \mathrm{C}$ with minimal sample preparation and has been used to amplify RNAs, miRNA, ssDNA and dsDNA from a wide variety of organisms (Lobato and O'Sullivan 2018). To address the requirements of amplification for use in low-resource settings, RPA is remarkable due to its simplicity, high sensitivity, selectivity and rapid amplification (results in 5-20 min), making it an affordable user-friendly POC device (Lobato and O'Sullivan 2018). The RPA technology was first developed in 2006 by Piepenburg et al. (2006) and is currently commercialised under the license of TwistDx Limited. The mechanism of RPA relies on a synthetically engineered adaptation of a natural cellular process called homologous recombination (a key process in DNA metabolism). The standard RPA reaction reagents comprise three key proteins, (i) recombinase, (ii) recombinase loading factor, and (iii) single-stranded binding protein, which subsequently coordinate with additional components such as dNTPs, DNA polymerase, ATP, crowding agents (polyethyleneglycol) and salt molecules to perform the reaction ( $\mathrm{Li}$ et al. 2020). The RPA process starts with binding of the recombinase protein to the primers assisted by the recombinase loading factor in presence of ATP and the crowding agent, forming the recombinase-primer complex (Lobato and Sullivan 2018). The complex then searches for their homologous sequences in the duplex DNA and invades the duplex DNA forming a D-loop structure. The side of the D-loop that remains single-stranded is stabilized by the single-stranded binding protein ( $\mathrm{Li}$ et al. 2020). The recombinase then disassembles and a strand displacing DNA polymerase binds to the primer to elongate it in the presence of dNTPs. As the polymerisation continues, the two parental strands continue to separate, ultimately resulting in the exponential accumulation of amplified duplex DNA (Moore and Jaykus 2017). The amplified product can be detected by LFD assay, and the process is combinedly known as RPA-LFD. Multiple other techniques can also be used for RPA amplification product detection including agarose gel electrophoresis and real-time fluorescent detection (Tu et al. 2018).

In the recent years, a number of RPA-LFD assays have been developed for diagnosis of infectious animal diseases. RPA assays combined with a real-time fluorescent detection (real-time RPA assay) and lateral flow dipstick (RPA LFD assay) have been developed for rapid detection of goatpox virus and sheeppox virus (Yang et al. 2017a). RPA-LFD 
assay as an alternative to conventional ELISA for the screening of Bovine leukaemia virus (BLV) both at laboratory and field application has been recommended in a recent study ( $\mathrm{Tu}$ et al. 2018). Detection of the H9-subtype of Avian influenza virus by RPA LFD assay with $10 \times$ more sensitivity than conventional RT-PCR has also been documented (Wang et al. 2019). Several other significant animal diseases for which RPA-LFD assays have been developed include detection of Porcine circovirus type 2 (PCV-2) (Yang et al. 2017b), PPRV (Yang et al. 2017c), ASFV (Miao et al. 2019), Porcine deltacoronavirus (PDCoV) (Gao et al. 2020), Pasteurella multocida (Zhao et al. 2019), Bovine viral diarrhoea virus (BVDV) (Hou et al. 2018a), Bovine ephemeral fever virus (BEFV) (Hou et al. 2018b), Mycoplasma bovis (Zhao et al. 2018), Infectious bovine rhinotracheitis virus (IBRV) (Hou et al. 2017), FMDV (Wang et al. 2018b), Brucella species (Qin et al. 2019), PRRSV (Wang et al. 2017) and LSDV (Shalaby et al. 2016). The use of RPA-LFD assay in diagnostic application is therefore becoming a molecular tool of choice for the rapid, specific, and cost-effective approach for identification of animal diseases in laboratory settings as well as in field conditions.

\section{Loop-mediated isothermal amplification}

Loop-mediated isothermal amplification (LAMP) is an established isothermal nucleic acid amplification method developed in the year 2000 by Notomi et al. (2000). LAMP has gained a significant interest among researchers and industries because of its high specificity, efficiency, and rapidity. The LAMP reaction can be completed in a water bath or heat block with an optimum temperature range between $60-65^{\circ} \mathrm{C}$ (Venkatesan et al. 2020). The assay uses four specially designed primers capable of recognizing six different regions in the target DNA, making the process highly specific (Venkatesan et al. 2020). However, the currently improved LAMP assays employ a total of six primers, recognising eight distinct sites of the target sequence (Nagamine et al. 2002), making the specificity of the assay extremely high.

The LAMP assay relies on auto-cycling strand displacement DNA synthesis, performed by a DNA polymerase with high strand displacement activity and a set of two specially designed inner and two outer primers (Notomi et al. 2000). The assay initially utilizes the inner forward primer containing two target sequences specific to two different regions in the template DNA and starts complementary strand synthesis (Silva et al. 2020). The outer primers then hybridize the sequence in the target DNA releasing a single-stranded DNA. The single-stranded DNA then serves as a template for DNA synthesis primed by the second inner and outer primers that hybridize to the other end of the target, producing a stem loop DNA (Notomi et al. 2000). In the subsequent process, one inner primer hybridizes to the loop on the product and initiates displacement DNA synthesis, yielding the original stem loop and a new stem loop, and the cycling reaction continues (Notomi et al. 2000). For the amplification of RNA viruses, a reverse transcription step is undertaken prior to the LAMP reaction.

Several LAMP assays have been developed in the recent years for detection of animal diseases in field and resource-limited settings. A comprehensive list of LAMP techniques developed for diagnosis of important animal diseases has been tabulated (Table 2).

\section{Linear-after-the-exponential polymerase chain reaction}

Linear-after-the-exponential polymerase chain reaction (LATE-PCR), first described by Sanchez et al. (2004) is a novel approach to asymmetric PCR. LATEPCR can utilize as few as a single DNA/RNA molecule and primers are designed with adjusted melting temperatures to increase the amplification efficiency (Pierce et al. 2010). The standard reaction process of LATE-PCR consists of a limiting primer, excess primer and a molecular beacon (mismatch-tolerant probe) 
Table 2. Loop-mediated isothermal amplification (LAMP) assay developed for existing and emerging animal diseases.

\begin{tabular}{|c|c|c|}
\hline Animal disease & Target genes/organisms & References \\
\hline Anthrax & $\begin{array}{l}\text { B. anthracis pag gene (encoding protective } \\
\text { antigen portion of anthrax toxin) } \\
\text { B. anthracis spores }\end{array}$ & $\begin{array}{l}\text { Upadhyay et al. } 2020 \\
\text { Jain et al. } 2011\end{array}$ \\
\hline Blue tongue & BTV genome segment 1 & Maan et al. 2016 \\
\hline Bovine brucellosis & Conserved BruAb2 0168 region of $B$. abortus & $\begin{array}{l}\text { Karthik et al. } 2014 \text {; } \\
\text { Kang et al. } 2015\end{array}$ \\
\hline Foot-and-mouth disease & $\begin{array}{l}\text { FMDV 2B } \\
\text { FMDV-3D pol }\end{array}$ & $\begin{array}{l}\text { Chen et al. } 2011 \\
\text { Farooq et al. } 2015\end{array}$ \\
\hline Haemorrhagic septicaemia & P. multocida KMT1 gene & $\begin{array}{l}\text { Sun et al. 2010; } \\
\text { Bhimani et al. } 2015\end{array}$ \\
\hline $\begin{array}{l}\text { Capripox virus infections } \\
\text { (LSD and goat pox) }\end{array}$ & CaPV-VP39 gene and P32 gene & Mwanandota et al. 2018 \\
\hline Camelpox virus infections & CMLV-C18L gene & Venkatesan et al. 2012 \\
\hline Peste-des-petits-ruminants & PPRV-Nucleocapsid gene & $\begin{array}{l}\text { Mahapatra et al. } 2019 ; \\
\text { Rajko-Nenow et al. } 2019\end{array}$ \\
\hline African swine fever & $\begin{array}{l}\text { ASFV-VP73 gene, putative DNA primase } \\
\text { and Topoisomerase II genes }\end{array}$ & James et al. 2010 \\
\hline Classical swine fever & $\begin{array}{l}\text { CSFV 5' NTR } \\
\text { CSFV NS5B gene and 5' NTR }\end{array}$ & $\begin{array}{l}\text { Chowdry et al. } 2014 \\
\text { Postel et al. } 2015\end{array}$ \\
\hline $\begin{array}{l}\text { Rabies } \\
\text { Vesicular stomatitis }\end{array}$ & $\begin{array}{l}\text { RABV-Nucleoprotein gene } \\
\text { VSV-Spanning nucleotides 1376-1598 } \\
\text { (junction between nucleocapsid } \\
\text { and phosphoprotein) }\end{array}$ & Saitou et al. 2010 \\
\hline Bovine viral diarrhoea & BVDV- 5'UTR & Fan et al. 2012 \\
\hline Bovine tuberculosis & M. bovis cell surface lipoprotein mpt83 & Zhang et al. 2011 \\
\hline Rift Valley fever & RVFV S RNA segment & Han et al. 2020 \\
\hline West Nile fever & WNFV Envelope gene & Parida et al. 2004 \\
\hline Porcine reproductive & PRRSV-ORF6 & Li et al. 2009 \\
\hline and respiratory syndrome & PRRSV-Nucleocapsid gene & Park et al. 2016 \\
\hline Porcine circovirus 2 infections & PCV-2 Capsid (cap) gene & Chen et al. 2008 \\
\hline Porcine circovirus 3 infections & $\begin{array}{l}\text { PCV-3 ORF2 } \\
\text { PCV-3 cap gene }\end{array}$ & $\begin{array}{l}\text { Zheng et al. } 2018 \\
\text { Park et al. } 2018\end{array}$ \\
\hline $\begin{array}{l}\text { Porcine epidemic diarrhoea } \\
\text { Novel swine acute diarrhoea }\end{array}$ & PEDV Membrane gene & Yu et al. 2015 \\
\hline $\begin{array}{l}\text { syndrome coronavirus } \\
\text { Porcine deltacoronavirus }\end{array}$ & SADS-CoV Nucleocapsid gene & Wang et al. 2018a \\
\hline infections & PDCoV Nucleocapsid gene & Zhang et al. 2017 \\
\hline $\begin{array}{l}\text { Porcine pegivirus infections } \\
\text { Japanese encephalitis virus }\end{array}$ & PPgV NS5A gene & Li et al. 2019 \\
\hline infection & JEV Envelope gene & Liu et al. 2012 \\
\hline Contagious ecthyma & $\begin{array}{l}\text { Orf virus-B2L gene } \\
\text { Orf virus F1L gene }\end{array}$ & $\begin{array}{l}\text { Venkatesan et al. } 2016 \\
\text { Wang et al. } 2015\end{array}$ \\
\hline
\end{tabular}

B. anthracis - Bacillus anthracis; BTV - Blue tongue virus; B. abortus - Brucella abortus; FMDV - Foot-andmouth disease virus; P. multocida - Pasteurella multocida; CaPV - Capripox virus; CMLV - Camelpox virus; PPRV - Peste-des-petits-ruminants virus; ASFV - African swine fever virus; CSFV - Classical swine fever virus; RABV - Rabies virus; VSV - Vesicular stomatitis virus; BVDV - Bovine viral diarrhoea virus; M. bovis - Mycobacterium bovis; RVFV - Rift Valley fever virus; WNF - West Nile fever virus; PRRSV - Porcine reproductive and respiratory syndrome virus; PCV-2 - Porcine circovirus 2; PCV-3 - Porcine circovirus 3; PEDV - Porcine epidemic diarrhoea virus; SADS-CoV - Swine acute diarrhoea syndrome coronavirus; PDCoV - Porcine deltacoronavirus; $\mathrm{PPgV}$ - Porcine pegivirus; JEV - Japanese encephalitis virus 
(Johann et al. 2015). LATE-PCR begins with an exponential phase in which amplification efficiency is similar to that of conventional symmetric PCR. Once the limiting primer is depleted, the reaction abruptly switches to linear amplification, and the single-stranded product is made for many additional thermal cycles. The accumulating single-stranded products will have no complementary strands and are therefore will be free to hybridize to the probe emitting fluorescent signals (Pierce et al. 2005). The most known application of LATE PCR is in FMDV serotyping, in which the field strains with novel sequence mutations can be detected through fluorescent signals (Pierce et al. 2010).

\section{Future diagnostic models}

\section{Microfluidics}

Microfluidics is an emerging technology of the recent years because of its significant application in the field of chemistry, biology, medicine, and physical sciences (Bragheri et al. 2020). The microfluidic technology involves the manipulation of small volumes of fluids, typically in nano or microlitres $\left(10^{-9}-10^{-6} 1\right)$ within networks of channels that have dimensions of tens to hundreds of micrometres (Busin et al. 2016). The concept of microfluidics constitutes the basis of integrated systems known as micro total analysis systems or lab-on-a-chip (LOC), which means the part of the chip acts as a part of the lab (Zhang and Hoshino 2018). The LOC device comprises of integrated microsystems embedded inside the chip (usually made of silicon or glass) such as microchannels, filters, pumps, valves and mixers which can be designed as a diagnostic assay (Shirzadfar and Khanahmadi 2018) and can be applied to steamline the complex assay protocols of detecting infectious diseases. However, there has been a very limited application of this technology in the veterinary field to date (Busin et al. 2016). Such fully automated microfluidic platform has been developed only recently, for multiplex detection of high threat livestock diseases such as FMD, classical swine fever (CSF) and vesicular stomatitis (VS) (Lung et al. 2019). Another feature of microfluidic technology includes microfluidic paper-based analytical devices (Busin et al. 2016). A recent application of microfluidic paper-based devices has been developed for detection of Bovine herpesvirus 1 (BoHV-1), Brucella and Leptospira species (Yang et al. 2018). A hybrid paper-based microfluidic platform compatible with 96-well microplates has been recently developed for rapid and low-cost translation and optimization of laboratory-based ELISA assay into paper ELISA (Busin et al. 2018).

\section{Biosensors}

Recent advances in biosensor technologies have the potential to match or surpass the conventional diagnostics with respect to sensitivity, selectivity, accuracy and cost (Du and Zhou 2018). A biosensor is an integrated receptor-transducer device that uses a biological recognition element to provide selective, quantitative or semi-quantitative information. Most biosensor technology relating to disease-related detection employ a transducer that converts a biological recognition event into a detectable signal (electrochemical, optical or piezoelectric) and displays the presence, concentration, or reaction process of the target biomarker in the analyte ( $\mathrm{Du}$ and Zhou 2018). Modern sensor technologies such as fluorescence resonance energy transfer and quantum dots (Zhang et al. 2015) have been developed for rapid and sensitive detection of several animal pathogens such as PRRSV, FMDV, BHV-1 and BVDV (Neethirajan et al. 2017). Novel diagnostic approach based on biosensing and photonic technologies have been developed for detection of emerging and endemic viruses which include ASFV, PRRSV, Swine influenza A virus (SIV), Porcine parvovirus (PPV), PCV-2 and CSFV (Montagnese et al. 2019). Another cutting-edge 
sensor technology is based on surface plasmon resonance (SPR) (Neethirajan 2017). The SPR sensors provide sensitive, label-free and real-time monitoring of reactions and can quantify the characteristics of biomolecular (e.g., oligonucleotides, proteins, viruses, bacteria etc.) interactions on a surface, including their kinetics, affinity and concentration (Skottrup et al. 2008). In recent years, SPR biosensors have been used to detect avian influenza A viruses: H5N1 (Bai et al. 2012) and H7N9 (Chang et al. 2018), SIV: H1N1 (Yoo et al. 2020), CSF (Mustafa et al. 2014), PCV-2 (Hu et al. 2014), Leptospira species (Raikwar et al. 2020) and Brucella abortus (Gupta et al. 2011).

\section{Current status of non-invasive sampling strategies}

Non-invasive samples for diagnostic purposes have been increasingly used in different scientific studies. They consist of sampling techniques that do not require penetration of the skin or a mucosal barrier to obtain biological samples (Baneth 2015). The noninvasive samples include conjunctival, nasal and oral mucosal swabs, milk, oral fluids/saliva, hair, urine and faeces (Baneth 2015; Mengüllüoğlu et al. 2019). This technique has now become an alternative to invasive sampling methods (venous blood collection/aspirations of lymph nodes or the bone marrow) and has been widely used by biologists in wildlife research (Dib et al. 2019). Because of the obvious advantage of being relatively simple to employ and standardize, non-invasive sampling strategies hold great promise for studies that cover large areas to investigate diseases in free-ranging animals and atypical hosts that are logistically difficult and time consuming to capture and manipulate (Kelly et al. 2012). In the last two decades, various user-friendly techniques for collection and transport of non-invasive samples (oral fluids and swabs in particular) have been developed to be used in biomedical research (Segal and Wong 2008). Such innovative non-invasive techniques of sample collection can also be used for detection and surveillance of animal diseases. Research on animal diseases has demonstrated the potential of non-invasive samples for accurate diagnosis of livestock diseases, a number of which have been described:

\section{Oral fluids/saliva}

The use of oral fluids/saliva as a diagnostic fluid is a broadening perspective in clinical animal disease diagnosis and monitoring (Prickett and Zimmerman 2010). Saliva offers a source of locally produced and serum derived markers with non-invasive animal practices (Gutiérrez et al. 2017). Oral fluids serve as an efficient sample for detection of animal pathogens that might originate in affected tissues associated with the buccal cavity or reach the buccal cavity from the circulatory system via the oral mucosal transudate (OMT) (Prickett 2009). Saliva comprises primarily of secretory IgA (sIgA), whereas OMT contains a mixture of $\operatorname{sgA}, \operatorname{IgG}$ and $\operatorname{IgM}$, thus, provides a richer source of antibodies, including those directed against bacterial and viral pathogens (Corstjens et al. 2012). Detection of antigens in oral fluids have been confirmed in several animal diseases following natural as well as experimental infections such as PRRS and PCV-2 infections (Prickett 2009), Johne's disease (Sorge et al. 2013), FMD (Senthilkumaran et al. 2017), bovine papular stomatitis (Eirai et al. 2016), CSF (Beemer et al. 2019), ASF (Beemer et al. 2019) and PPR (Parida et al. 2019). Bearing in mind the animal diseases with a diverse host range such as PPR, ASF, FMD, rabies, canine distemper and coronavirus infections, oral fluid-based surveillance of pathogens, as a non-invasive and safe source, would be an efficient approach in diagnosis of animal diseases in domestic as well as in wildlife. More recently, rope-based oral fluid sampling has gained substantial importance in transboundary animal diseases for which effective population level sampling methods have not been available. Rope-in-a-bait based oral fluid sampling technique has been tested and found to be effective in early detection of FMDV infections of wild boars 
(Mouchantat et al. 2014a), CSF infections in wild boars (Mouchantat et al. 2014b) and domestic pigs (Dietze et al. 2016), and detection of ASFV in wild boars (Männistö 2018).

\section{Swabs}

Swabs (nasal, naso/oro-pharyngeal), as non-invasive samples, could be an excellent source of potential respiratory pathogens. The current example is detection of pandemic COVID-19 infections in humans as well as animals using naso pharyngeal swabs (Sit et al. 2020; Segalés et al. 2020). Research on infectious animal disease detection have proved that detection of viruses can be accurately received in molecular tests, isolation as well as in serology through use of nasal swabs (Dynon et al. 2007). Nasal swabs have proved to be suitable for FMDV detection by RT-PCR even during the asymptomatic stages of infection (Marquardt et al. 1995). Nasal swabs have shown to be effective in detection of other respiratory pathogens like BHV-1, Bovine parainfluenza 3 virus (BPI3V) (Gangil et al. 2020), Mycoplasma hyopneumoniae (Otagiri et al. 2005), Mycoplasma bovis and Mannheimia haemolytica (Godinho et al. 2007).

\section{Faecal samples}

Faecal samples as non-invasive samples have become a regular choice in wildlife biology, population monitoring and ecological research globally. Advantages of faecal sample-based wildlife research include easy collection, access to large sample sizes and spatio-temporal coverage (Biswas et al. 2019). Such faecal sampling protocol could be used for detection of infectious diseases in herbivores (elephants and other wild ungulates) as well as in carnivores. Elephant endotheliotropic herpes virus (EEHV) infection is a highly fatal disease in young Asian elephants. The virus is ubiquitous in elephants. The samples that are used regularly for diagnosis of the infection are trunk washings, blood, and oral swabs. But these samples are difficult to obtain from elephants in the wild as the technique is invasive. The non-invasive technique of sampling is highly essential in such instances. The non-invasive sampling for EEHV was done by collecting chewed plant and faeces (Jeffrey et al. 2020). Bataille et al. (2019), concluded in their study on PPR that faecal samples can be collected non-invasively from the artiodactyls which can be used for surveillance and control of the disease.

\section{Bioaerosol sampling}

Bioaerosol or aerosol sampling is a novel concept of non-invasive approach which can be used for detection of emerging viruses, mostly of respiratory origin. In the recent decade, emerging zoonotic viruses like Severe acute respiratory syndrome coronavirus (SARS CoV), MERS-CoV, avian strains of IAV (eg, H5N1, H7N9, and H9N2), and most recently the SARS-CoV-2 pandemics have led to considerable mortality and morbidity in humans and animals (Wang et al. 2020; Oreshkova et al. 2020). High population density, international tourism and trade traffic have fuelled the risk of novel emerging respiratory epidemics. With the approach of bioaerosol sampling, such biological threats can be quickly identified and robustly tracked to initiate an early emergency response to novel pathogens (Coleman et al. 2018).

Bioaerosol sampling devices works by extracting a representative bioaerosol sample from an air environment and then preserving the bioaerosol sample properties needed for sample analysis by traditional and modern analysis techniques (Mainelis 2020). Various bioaerosol samplers have been developed that include (i) filtration and filter-based samplers, (ii) impaction-based samplers, (iii) agar-based samplers (iv), liquid-based samplers, and (v) electrostatic collection of micro-organisms (Mainelis 2020). In response to the spread of zoonotic infectious disease through air, bioaerosol sampling techniques have been 
adapted for (i) influenza virus detection in live animal markets (Zhou et al. 2016; Wang et al. 2020), swine production facilities (Poh et al. 2017), mass rapid transit networks (Coleman et al. 2018) as well as in airport settings (Bailey et al. 2018). Bio-aerosol sampling has an advantage as a non-invasive sampling approach since it is accepted by animal vendors at live markets as well as in production facilities. Therefore, bioaerosol sampling can be an effective screening tool for emerging and novel viruses which can be followed up with traditional method of swabbing if evidence of a novel virus is found (Wang et al. 2020).

\section{Conclusion}

The status of global animal disease epidemiology is complicated by threats of both existing and emerging infectious diseases. These challenges highlight the need for rapid and specific diagnosis, coupled with timely initiation of appropriate treatment in order to prevent and control the spread of infectious or zoonotic diseases, thereby protecting human health and safety. During the last decade, point of care diagnostics have gained their impact in several fields such as infectious disease diagnosis, animal health management and animal reproduction. POCDs such as Ag-LFDs, RPA-LFD and LAMP have been extensively researched and developed considering their obvious advantages over traditional laboratory-based diagnostics which usually involves laborious and expensive laboratory techniques and dedicated technical personnel. In addition, non-invasive approach of sample collection coupled with a point-of-care test can be of particular importance in diagnosis of economically important and emerging animal pathogens of domestic and wildlife in field-based settings. While economic benefits of POCDs and better outcomes with respect to the conventional diagnostics are still discussed, it is likely that these tests will gain further importance in veterinary medicine in near future with decreasing processing costs and improved robustness.

\section{Acknowledgements}

The authors acknowledge the Dean, Faculty of Veterinary and Animal Sciences (FVAS), Banaras Hindu University and the Director of Research, College of Veterinary Sciences, Assam Agricultural University, India for providing opportunity to explore the possibility of this study.

\section{References}

Al-Zi'abi O, Nishikawa H, Meyer H 2007: The first outbreak of camelpox in Syria. J Vet Sci 69: 541-543

Anderson J, McKay JA, Butcher RN 1990: Seromonitoring of rinderpest throughout Africa: phase one. In: Proceedings of the final research coordination meeting of the IAEA rinderpest control projects, Côte d'Ivoire, pp. 19-23

Bai H, Wang R, Hargis B, Lu H, Li Y 2012: A SPR aptasensor for detection of avian influenza virus H5N1. Sensors 12: 12506-12518

Bailey ES, Choi JY, Zemke J, Yondon M, Gray GC 2018: Molecular surveillance of respiratory viruses with bioaerosol sampling in an airport. Trop Dis Travel Med Vaccines 4: 1-5

Balogh EP, Miller BT, Ball JR 2015: Committee on Diagnostic Error in Health Care; Board on Health Care Services; Institute of Medicine; Improving Diagnosis in Health Care. Washington, D.C., USA, National Academies Press

Baneth G 2015: Invasive and non-invasive diagnostic techniques for pet infectious diseases. In: Proceedings of the 40 ${ }^{\text {th }}$ World Small Animal Veterinary Association Congress, Bangkok, Thailand, 15-18 May, pp. 450-451. World Small Animal Veterinary Association

Baron J, Fishbourne E, Couacy-Hyman E, Abubakar M, Jones BA, Frost L, Herbert R, Chibssa TR, Van't Klooster G, Afzal M, Ayebazibwe C 2014: Development and testing of a field diagnostic assay for peste des petits ruminants virus. Transbound Emerg Dis 61: 390-396

Bataille A, Kwiatek O, Belfkhi S, Mounier L, Parida S, Mahapatra M, Caron A, Chubwa CC, Keyyu J, Kock R, Jones BA, Libeau G 2019: Optimization and evaluation of a non-invasive tool for peste des petits ruminants surveillance and control. Sci Rep 9: 4742

Beemer O, Remmenga M, Gustafson L, Johnson K, His D, Antognoli MC 2019: Assessing the value of PCR assays in oral fluid samples for detecting African swine fever, classical swine fever, and foot-and-mouth disease in US swine. PloS One 14: e0219532 
Bhimani MP, Bhanderi BB, Roy A 2015: Loop mediated Isothermal Amplification assay (LAMP) based detection of Pasteurella multocida in cases of haemorrhagic septicaemia and fowl cholera. Vet Ital 51: 115-121

Biogal Galed Labs 2015: Immunocomb. Bovine Neospora Antibody Test Kit. Available at http://www.agrolabo. it/wp-content/uploads/immunoc-bovine-neospora.pdf

Biswas S, Bhatt S, Paul S, Modi S, Ghosh T, Habib B, Nigam P, Talukdar G, Pandav B, Mondol S 2019: A practive faeces collection protocol for multidisciplinary research in wildlife science. BioRxiv: 537803

Bragheri F, Vázquez RM, Osellame R 2020: Microfluidics. In: Three-Dimensional Microfabrication Using TwoPhoton Polymerization, William Andrew Publishing, pp. 493-526

Busin V, Wells B, Kersaudy-Kerhoas M, Shu W, Burgess ST 2016: Opportunities and challenges for the application of microfluidic technologies in point-of-care veterinary diagnostics. Mol Cell Probes 30: 331-341

Busin V, Burgess S, Shu W 2018: A hybrid paper-based microfluidic platform toward veterinary P-ELISA. Sens Actuators B Chem 273: 536-542

Cêtre-Sossah C, Pédarrieu A, Juremalm M, Jansen Van Vuren P, Brun A, Ould El Mamy AB, Héraud JM, Filippone C, Ravalohery JP, Chaabihi H, Albina E 2019: Development and validation of a pen side test for Rift Valley fever. PLOS Negl Trop Dis 13: e0007700

Chang YF, Wang WH, Hong YW, Yuan RY, Chen KH, Huang YW, Lu PL, Chen YH, Chen YM, Su LC, Wang SF 2018: Simple strategy for rapid and sensitive detection of avian influenza A H7N9 virus based on intensitymodulated SPR biosensor and new generated antibody. Anal Chem 90: 1861-1869

Chen HT, Zhang J, Liu YS, Liu XT 2011: Detection of foot-and-mouth disease virus RNA by reverse transcription loop-mediated isothermal amplification. Virol J 8: 510

Chen HT, Zhang J, Sun DH, Chu YF, Cai XP, Liu XT, Luo XN, Liu Q, Liu YS 2008: Rapid detection of porcine circovirus type 2 by loop-mediated isothermal amplification. J Virol Methods 149: 264-268

Chowdry VK, Luo Y, Widén F, Qiu HJ, Shan H, Belák S, Liu L 2014: Development of a loop-mediated isothermal amplification assay combined with a lateral flow dipstick for rapid and simple detection of classical swine fever virus in the field. J Virol Methods 197: 14-18

Coleman KK, Nguyen TT, Yadana S, Hansen-Estruch C, Lindsley WG, Gray GC 2018: Bioaerosol sampling for respiratory viruses in Singapore's mass rapid transit network. Sci Rep 8: 1-7

Corstjens PL, Abrams WR, Malamud D 2012: Detecting viruses by using salivary diagnostics. J Am Dent Assoc 143: $12 \mathrm{~S}-18 \mathrm{~S}$

de Puig H, Bosch I, Gehrke L, Hamad-Schifferli K 2017: Challenges of the nano-bio interface in lateral flow and dipstick immunoassays. Trends Biotechnol 35: 1169-1180

Dib LV, Palmer JP, Bastos OM, Uchôa CM, Amendoeira MR, Bastos AC 2019: Noninvasive Sampling: Monitoring of Wild Carnivores and Their Parasites. In: Protected Areas, National Parks and Sustainable Future, IntechOpen

Dietze K, Tucakov A, Engel T, Wirtz S, Depner K, Globig A, Kammerer R, Mouchantat S 2016: Rope-based oral fluid sampling for early detection of classical swine fever in domestic pigs at group level. BMC Vet Res 13: 1-6

Dikid T, Jain SK, Sharma A, Kumar A, Narain JP 2013: Emerging \& re-emerging infections in India: an overview. Indian J Med Res 138: 19-31

Du X, Zhou J 2018: Application of biosensors to detection of epidemic diseases in animals. Res Vet Sci 118: 444-448

Dynon K, Black WD, Ficorilli N, Hartley CA, Studdert MJ 2007: Detection of viruses in nasal swab samples from horses with acute, febrile, respiratory disease using virus isolation, polymerase chain reaction and serology. Aust Vet J 85: 46-50

Eirai S, Nakanishi A, Yasukawa Y, Moriyama M, Konishi M, Inoshima Y 2016: Occurrence and spread of bovine papular stomatitis with different types of lesions among Japanese black calves suspected of having foot-andmouth disease. J Vet Med Sci 69: 323-328

Engering A, Hogerwerf L, Slingenbergh J 2013: Pathogen-host-environment interplay and disease emergence. Emerg Microbes Infect 2: 1-7

Erster O, Melamed S, Paran N, Weiss S, Khinich Y, Gelman B, Solomony A, Laskar-Levy O 2018: First diagnosed case of camelpox virus in Israel. Viruses 10: 78

Fan Q, Xie Z, Xie L, Liu J, Pang Y, Deng X, Xie Z, Peng Y, Wang X 2012: A reverse transcription loop-mediated isothermal amplification method for rapid detection of bovine viral diarrhea virus. J Virol Methods 186: 43-48

FAO 2011: Challenges of Animal Health Informations Systems and Surveillance for Animal Diseases and Zoonoses

FAO 2012: Lessons learned from the eradication of rinderpest for controlling other transboundary animal diseases. In: Proceedings of the GREP Symposium and High-Level Meeting, 12-15 October 2010, Rome, Italy. FAO Animal Production and Health Proceedings, No. 15. Rome, Italy

FAO, OIE 2015: Global strategy for the control and eradication of PPR

FAO, OIE 2020: Global control of African swine fever: A GF-TADs initiative. 2020-2025. Paris. Available at http://www.fao.org/3/ca9164en/CA9164EN.pdf

Farooq U, Latif A, Irshad H, Ullah A, Zahur AB, Naeem K, Khan SH, Ahmed Z, Rodriguez LL, Smoliga G 2015 : Loop-mediated isothermal amplification (RT-LAMP): a new approach for the detection of foot-and-mouth disease virus and its sero-types in Pakistan. Iran. J Vet Res 16: 331-334 
Ferris NP, Clavijo A, Yang M, Velazquez-Salinas L, Nordengrahn A, Hutchings GH, Kristersson T, Merza M 2012: Development and laboratory evaluation of two lateral flow devices for the detection of vesicular stomatitis virus in clinical samples. J Virol Methods 180: 96-100

Ferris NP, Nordengrahn A, Hutchings GH, Paton DJ, Kristersson T, Brocchi E, Grazioli S, Merza M 2010: Development and laboratory validation of a lateral flow device for the detection of serotype SAT 2 foot-andmouth disease viruses in clinical samples. J Virol Methods 163: 474-476

Fowler VL, Howson EL, Madi M, Mioulet V, Caiusi C, Pauszek SJ, Rodriguez LL, King DP 2016: Development of a reverse transcription loop-mediated isothermal amplification assay for the detection of vesicular stomatitis New Jersey virus: Use of rapid molecular assays to differentiate between vesicular disease viruses. J Virol Methods 234: 123-131

Gandon S, Hochberg ME, Holt RD, Day T 2013: What limits the evolutionary emergence of pathogens? Philos Trans R Soc Lond B Biol Sci 368: 20120086

Gangil R, Kaur G, Dwivedi PN 2020: Detection of respiratory viral antigens in nasal swabs of bovine by sandwich ELISA. Indian J Anim Res 54: 354-358

Gao X, Liu X, Zhang Y, Wei Y, Wang Y 2020: Rapid and visual detection of porcine deltacoronavirus by recombinase polymerase amplification combined with a lateral flow dipstick. BMC Vet Res 16: 1-8

Gaudreault NN, Indran SV, Balaraman V, Wilson WC, Richt JA 2019: Molecular aspects of Rift Valley fever virus and the emergence of reassortants. Virus Genes 55: 1-11

Gilor S, Gilor C 2011: Common laboratory artifacts caused by inappropriate sample collection and transport: how to get the most out of a sample. Top Companion Anim Med 26: 109-118

Godinho KS, Sarasola P, Renoult E, Tilt N, Keane S, Windsor GD, Rowan TG, Sunderland SJ 2007: Use of deep nasopharyngeal swabs as a predictive diagnostic method for natural respiratory infections in calves. Vet Rec 160: 22

Gupta G, Kumar A, Boopathi M, Thavaselvam D, Singh B, Vijayaraghavan R 2011: Rapid and quantitative determination of biological warfare agent Brucella abortus CSP-31 using surface plasmon resonance. Anal Bioanal Electrochem 3: 26-37

Gutiérrez AM, De La Cruz-Sánchez E, Montes A, Sotillo J, Gutiérrez-Panizo C, Fuentes P, Tornel PL, CabezasHerrera J 2017: Easy and non-invasive disease detection in pigs by adenosine deaminase activity determinations in saliva. PLoS One 12: e0179299

Han Q, Zhang S, Liu D, Yan F, Wang H, Huang P, Bi J, Jin H, Feng N, Cao Z, Gao Y 2020: Development of a visible reverse transcription-loop-mediated isothermal amplification assay for the detection of Rift Valley fever virus. Front Microbiol 11: 590732

Hou P, Wang H, Zhao G, He C, He H 2017: Rapid detection of infectious bovine rhinotracheitis virus using recombinase polymerase amplification assays. BMC Vet Res 13: 386

Hou P, Zhao G, Wang H, He C, He H 2018a: Rapid detection of bovine viral diarrhea virus using recombinase polymerase amplification combined with lateral flow dipstick assays in bulk milk. Vet Arh 88: 627-642

Hou P, Zhao G, Wang H, He C, Huan Y, He H 2018b: Development of a recombinase polymerase amplification combined with lateral-flow dipstick assay for detection of bovine ephemeral fever virus. Mol Cell Probes 38: 31-37

Howson E, Soldan A, Webster K, Beer M, Zientara S, Belak S, Sanchez-Vizcaino JM, Van Borm S, King DP, Fowler VL 2017: Technological advances in veterinary diagnostics: opportunities to deploy rapid decentralised tests to detect pathogens affecting livestock. Rev Sci Tech Off Int Epiz 36: 479-498

Hu J, Wang T, Wang S, Chen M, Wang M, Mu L, Chen H, Hu X, Liang H, Zhu J, Jiang M 2014: Development of a surface plasmon resonance biosensing approach for the rapid detection of porcine circovirus type 2 in sample solutions. PloS One 9: e111292

IDEXX BVDV: Ag Point-of-Care Test. Available at https://www.idexx.com/en/livestock/livestock-tests/ ruminant-tests/idexx-bvdv-ag-point-care-test/

Jain N, Kumar JS, Parida MM, Merwyn S, Rai GP, Agarwal GS 2011: Real-time loop-mediated isothermal amplification assay for rapid and sensitive detection of anthrax spores in spiked soil and talcum powder. World J Microbiol Biotechnol 27: 1407-1413

James HE, Ebert K, McGonigle R, Reid SM, Boonham N, Tomlinson JA, Hutchings GH, Denyer M, Oura CA, Dukes JP, King DP 2010: Detection of African swine fever virus by loop-mediated isothermal amplification. J Virol Methods 164: 68-74

Jeffrey A, Evans TS, Molter C, Howard LL, Ling P, Goldstein T, Gilardi K 2020: Noninvasive sampling for detection of elephant endotheliotropic herpesvirus and genomic DNA in Asian (Elephas maximus) and African (Loxodonta africana) elephants. J Zoo Wildl Med 51: 433-437

Johann KS, Schürenkamp M, Sibbing U, Lischka C, Pfeiffer H, Vennemann M 2015: Linear-after-the-exponential (LATE)-PCR: improved asymmetric PCR for quantitative DNA-analysis. Forensic Sci Int Genet Suppl Ser 5: e659-e661

Kang B, Oh J, Lee C, Park BK, Park Y, Hong K, Lee K, Cho B, Song D 2007: Evaluation of a rapid immunodiagnostic test kit for rabies virus. J Virol Methods 145: 30-36

Kang SI, Her M, Kim JY, Lee JJ, Lee K, Sung SR, Jung SC 2015: Rapid and specific identification of Brucella abortus using the loop-mediated isothermal amplification (LAMP) assay. Comp Immunol Microbiol Infect Dis 40: 1-6 
Karthik K, Rathore R, Thomas P, Arun TR, Viswas KN, Agarwal RK, Manjunathachar HV, Dhama K 2014: Loop-mediated isothermal amplification (LAMP) test for specific and rapid detection of Brucella abortus in cattle. Vet Q 34: 174-179

Kelly MJ, Betsch J, Wultsch C, Mesa B, Mills LS 2012: Noninvasive sampling for carnivores. In: Carnivore Ecology and Conservation: a Handbook of Techniques, pp. 47-69

Kisaakye E, Ario AR, Bainomugisha K, Cossaboom CM, Lowe D, Bulage L, Kadobera D, Sekamatte M, Lubwama B, Tumusiime D, Tusiime P 2018: Outbreak of anthrax associated with handling and eating meat from a cow, Uganda, 2018. Emerg Infect Dis 26: 2799-2806

Koczula KM, Gallotta A 2016: Lateral flow assays. Essays Biochem 60: 111-120

Kolton CB, Marston CK, Stoddard RA, Cossaboom C, Salzer JS, Kozel TR, Gates-Hollingsworth MA, Cleveland CA, Thompson AT, Dalton MF, Yabsley MJ 2019: Detection of Bacillus anthracis in animal tissues using InBios active anthrax detect rapid test lateral flow immunoassay. Lett Appl Microbiol 68: 480-484

Lagare A, Fall G, Ibrahim A, Ousmane S, Sadio B, Abdoulaye M, Alhassane A, Mahaman AE, Issaka B, Sidikou F, Zaneidou M 2019: First occurrence of Rift Valley fever outbreak in Niger, 2016. Vet Med Sci 5: 70-78

Li H, Li K, Bi Z, Gu J, Song D, Lei D, Luo S, Huang D, Wu Q, Ding Z, Wang L 2019: Development of a reverse transcription-loop-mediated isothermal amplification (RT-LAMP) assay for the detection of porcine pegivirus. J Virol Methods 270: 59-65

Li J, Macdonald J, von Stetten F 2020: Correction: Review: a comprehensive summary of a decade development of the recombinase polymerase amplification. Analyst 145: 1950-1960

Li Q, Zhou QF, Xue CY, Ma JY, Zhu DZ, Cao YC 2009: Rapid detection of porcine reproductive and respiratory syndrome virus by reverse transcription loop-mediated isothermal amplification assay. J Virol Methods 155: $55-60$

Liu H, Liu ZJ, Jing J, Ren JQ, Liu YY, Guo HH, Fan M, Lu HJ, Jin NY 2012: Reverse transcription loop-mediated isothermal amplification for rapid detection of Japanese encephalitis virus in swine and mosquitoes. Vector Borne Zoonotic Dis 12: 1042-1052

Lobato IM, O'Sullivan CK 2018: Recombinase polymerase amplification: basics, applications and recent advances. Trends Anal Chem 98: 19-35

Lung O, Fisher M, Erickson A, Nfon C, Ambagala A 2019: Fully automated and integrated multiplex detection of high consequence livestock viral genomes on a microfluidic platform. Transbound Emerg Dis 66: 144-155

Maan S, Maan NS, Batra K, Kumar A, Gupta A, Rao PP, Hemadri D, Reddy YN, Guimera M, Belaganahalli MN, Mertens PP 2016: Reverse transcription loop-mediated isothermal amplification assays for rapid identification of eastern and western strains of bluetongue virus in India. J Virol Methods 234: 65-74

Maclachlan NJ, Guthrie AJ 2010: Re-emergence of bluetongue, African horse sickness, and other orbivirus diseases. Vet Res 41: 35

Mahapatra M, Howson E, Fowler V, Batten C, Flannery J, Selvaraj M, Parida S 2019: Rapid detection of peste des petits ruminants virus (PPRV) nucleic acid using a novel low-cost reverse transcription loop-mediated isothermal amplification (RT-LAMP) assay for future use in nascent PPR eradication programme. Viruses 11: 699

Mainelis G 2020: Bioaerosol sampling: Classical approaches, advances, and perspectives. Aerosol Sci Technol 54: $496-519$

Männistö HE 2018: Collection of oral fluid samples from wild boar in the field conditions to detect African swine fever virus (ASFV) (Master's Degree thesis, Eesti Maaülikool).

Marquardt O, Straub OC, Ahl R, Haas B 1995: Detection of foot-and-mouth disease virus in nasal swabs of asymptomatic cattle by RT-PCR within 24 hours. J Virol Methods 53: 255-261

McElwain TF, Thumbi SM 2017: Animal pathogens and their impact on animal health, the economy, food security, food safety and public health. Rev Sci Tech (International Office of Epizootics) 36: 423-433

Mengüllüoğlu D, Fickel J, Hofer H, Förster DW 2019: Non-invasive faecal sampling reveals spatial organization and improves measures of genetic diversity for the conservation assessment of territorial species: Caucasian lynx as a case species. PloS One 14: e0216549

Miao F, Zhang J, Li N, Chen T, Wang L, Zhang F, Mi L, Zhang J, Wang S, Wang Y, Zhou X 2019: Rapid and sensitive recombinase polymerase amplification combined with lateral flow strip for detecting African swine fever virus. Front Microbiol 10: 1004

Montagnese C, Barattini P, Giusti A, Balka G, Bruno U, Bossis I, Gelasakis A, Bonasso M, Philmis P, Dénes L, Peransi S 2019: A diagnostic device for in-situ detection of swine viral diseases: The SWINOSTICS project. Sensors 19: 407

Moore MD, Jaykus LA 2017: Recombinase polymerase amplification: a promising point-ofcare detection method for enteric viruses. Future Virol 12: 421-429

Mosaad AA, Abdel-Hamed AS, Fathalla SI, Ghazy AA, Elballal S, Elbagory A, Mahboub H, Gaafar K, Elgayar KE, Mohamed AS, Amin AI 2012: Sensitive and specific diagnostic assay for detection of tuberculosis in cattle. Glob Vet 8: $555-564$

Mouchantat S, Globig A, Böhle W, Petrov A, Strebelow HG, Mettenleiter TC, Depner K 2014a: Novel ropebased sampling of classical swine fever shedding in a group of wild boar showing low contagiosity upon experimental infection with a classical swine fever field strain of genotype 2.3. Vet Microbiol 170: 425-429 
Mouchantat S, Haas B, Böhle W, Globig A, Lange E, Mettenleiter TC, Depner K 2014b: Proof of principle: Noninvasive sampling for early detection of foot-and-mouth disease virus infection in wild boar using a rope-in-abait sampling technique. Vet Microbiol 172: 329-333

Mustafa NH, Allaudin ZN, Honari P, Toung OP, Lila MM 2014: Detection of classical swine fever virus by a surface plasmon resonance assay. Virol Mycol 3: 136

Mwanandota JJ, Macharia M, Ngeleja CM, Sallu RS, Yongolo MG, Mayenga C, Holton TA 2018: Validation of a diagnostic tool for the diagnosis of lumpy skin disease. Vet Dermatol 29: 532-e178

Nagamine K, Hase T, Notomi T 2002: Accelerated reaction by loop-mediated isothermal amplification using loop primers. Mol Cell Probes 16: 223-229

Neethirajan S 2017: Recent advances in wearable sensors for animal health management. Sens Biosensing Res 12: $15-29$

Neethirajan S, Tuteja SK, Huang ST, Kelton D 2017: Recent advancement in biosensors technology for animal and livestock health management. Biosens Bioelectron 98: 398-407

Nemoto M, Schofield W, Cullinane A 2019: The first detection of equine coronavirus in adult horses and foals in Ireland. Viruses 11: 946

Notomi T, Okayama H, Masubuchi H, Yonekawa T, Watanabe K, Amino N, Hase T 2000: Loop-mediated isothermal amplification of DNA. Nucleic Acids Res 28: e63

Oem JK, Ferris NP, Lee KN, Joo YS, Hyun BH, Park JH 2009: Simple and rapid lateral-flow assay for the detection of foot-and-mouth disease virus. Clin Vaccine Immunol 16: 1660-1664

OIE 2019a: Manual of Diagnostic Tests and Vaccines for Terrestrial Animals. Available at https:/www.oie.int/ standard-setting/terrestrial-manual/access-online/

OIE 2019b: Foot-and-mouth disease (Infection with Foot and Mouth Disease Virus) [Chapter 3.1. 8]. Manual of diagnostic tests and vaccines for terrestrial animals

OIE 2019c: Peste des petits ruminants (Infection with Peste des petits ruminants Virus) [Chapter 3.7.9]. Manual of diagnostic tests and vaccines for terrestrial animals

Oreshkova N, Molenaar RJ, Vreman S, Harders F, Munnink BB, Hakze-van Der Honing RW, Gerhards N, Tolsma P, Bouwstra R, Sikkema RS, Tacken MG 2020: SARS-CoV-2 infection in farmed minks, the Netherlands, April and May 2020. Euro Surveill 25: 2001005

Otagiri Y, Asai T, Okada M, Uto T, Yazawa S, Hirai H, Shibata I, Sato S 2005: Detection of Mycoplasma hyopneumoniae in lung and nasal swab samples from pigs by nested PCR and culture methods. J Vet Sci 67: 801-805

Parida M, Posadas G, Inoue S, Hasebe F, Morita K 2004: Real-time reverse transcription loop-mediated isothermal amplification for rapid detection of West Nile virus. J Clin Microbiol 42: 257-263

Parida S, Selvaraj M, Gubbins S, Pope R, Banyard A, Mahapatra M 2019: Quantifying levels of peste des petits ruminants (PPR) virus in excretions from experimentally infected goats and its importance for nascent PPR eradication programme. Viruses 11: 249

Park JY, Park S, Park YR, Kang DY, Kim EM, Jeon HS, Kim JJ, Kim WI, Lee KT, Kim SH, Lee KK 2016: Reverse-transcription loop-mediated isothermal amplification (RT-LAMP) assay for the visual detection of European and North American porcine reproductive and respiratory syndrome viruses. J Virol Methods 237: $10-13$

Park YR, Kim HR, Kim SH, Lee KK, Lyoo YS, Yeo SG, Park CK 2018: Loop-mediated isothermal amplification assay for the rapid and visual detection of novel porcine circovirus 3. J Virol Methods 253: 26-30

Piepenburg O, Williams CH, Stemple DL, Armes NA 2006: DNA detection using recombination proteins. PLoS Biol 4: e204

Pierce KE, Mistry R, Reid SM, Bharya S, Dukes JP, Hartshorn C, King DP, Wangh LJ 2010: Design and optimization of a novel reverse transcription linear-after-the-exponential PCR for the detection of foot-andmouth disease virus. J Appl Microbiol 109: 180-189

Pierce KE, Sanchez JA, Rice JE, Wangh LJ 2005: Linear-After-The-Exponential (LATE)-PCR: primer design criteria for high yields of specific single-stranded DNA and improved real-time detection. Proc Natl Acad Sci 102: $8609-8614$

Plowright W, Ferris RD 1962: Studies with rinderpest virus in tissue culture: the use of attenuated culture virus as a vaccine for cattle. Res Vet Sci 3: 172-182

Poh MK, Ma M, Nguyen TT, Su YC, Pena EM, Ogden BE, Gray GC 2017: Bioaerosol sampling for airborne respiratory viruses in an experimental medicine pig handling facility, Singapore. Southeast Asian J Trop Med Public Health 48: 828-835

Poonati R, Mallepaddi PC, Punati RD, Maity SN, Alapati KS, Polavarapu KK, Polavarapu R 2020: Development of rapid, sensitive and in-expensive point of care diagnostic method for brucellosis in dairy cattle at resourcelimited areas. Indian J Public Health Res Dev 11: 566-572

Postel A, Pérez LJ, Perera CL, Schmeiser S, Meyer D, Meindl-Boehmer A, Rios L, Austermann-Busch S, FriasLepoureau MT, Becher P 2015: Development of a new LAMP assay for the detection of CSFV strains from Cuba: a proof-of-concept study. Arch Virol 160: 1435-1448

Prickett JR 2009: Detection of viral pathogens of swine using oral fluid specimens. Graduate Theses and Dissertations, Iowa State University, 11013. Available at https://lib.dr.iastate.edu/etd/11013 
Prickett JR, Zimmerman JJ 2010: The development of oral fluid-based diagnostics and applications in veterinary medicine. Anim Health Res Rev 11: 207-216

Purse BV, Mellor PS, Rogers DJ, Samuel AR, Mertens PP, Baylis M 2005: Climate change and the recent emergence of bluetongue in Europe. Nat Rev Microbiol 3: 171-181

Pusterla N, Vin R, Leutenegger C, Mittel, LD, Divers TJ 2016: Equine coronavirus infection. In: Emerging and re-emerging infectious diseases of livestock, pp. 121-132

Qin L, Nan W, Wang Y, Zhang Y, Tan P, Chen Y, Mao K, Chen Y 2019: A novel approach for detection of Brucella using a real-time recombinase polymerase amplification assay. Mol Cell Probes 48: 101451

Raikwar S, Prajapati YK, Srivastava, DK, Maurya JB, Saini JP 2020: Detection of leptospirosis bacteria in rodent urine by surface plasmon resonance sensor using graphene. Photonic Sensors 11: 305-313

Rajkhowa TK, Jagan Mohanarao G, Gogoi A, Hauhnar L, Isaac L 2015: Porcine reproductive and respiratory syndrome virus (PRRSV) from the first outbreak of India shows close relationship with the highly pathogenic variant of China. Vet Q 35: 186-193

Rajko-Nenow P, Flannery J, Arnold H, Howson EL, Darpel K, Stedman A, Corla A, Batten C 2019: A rapid RT-LAMP assay for the detection of all four lineages of Peste des Petits Ruminants Virus. J Virol Methods 274: 113730

Rebollo B, Pérez T, Camuñas A, Pérez-Ramírez E, Llorente F, Sánchez-Seco MP, Jiménez-Clavero MÁ, Venteo Á 2018: A monoclonal antibody to DIII E protein allowing the differentiation of West Nile virus from other flaviviruses by a lateral flow assay. J Virol Methods 260: 41-44

Roeder P, Mariner J, Kock R 2013: Rinderpest: the veterinary perspective on eradication. Philos Trans R Soc Lond B Biol Sci 368: 20120139

Rohr JR, Barrett CB, Civitello DJ, Craft ME, Delius B, DeLeo GA, Hudson PJ, Jouanard N, Nguyen KH, Ostfeld RS, Remais JV 2019: Emerging human infectious diseases and the links to global food production. Nat Sustain 2: $445-456$

Sailleau C, Breard E, Viarouge C, Vitour D, Romey A, Garnier A, Fablet A, Lowenski S, Gorna K, Caignard G, Pagneux C 2017: Re-emergence of bluetongue virus serotype 8 in France, 2015. Transbound Emerg Dis 64: 998-1000

Saitou Y, Kobayashi Y, Hirano S, Mochizuki N, Itou T, Ito FH, Sakai T 2010: A method for simultaneous detection and identification of Brazilian dog-and vampire bat-related rabies virus by reverse transcription loop-mediated isothermal amplification assay. J Virol Methods 168: 13-17

Sajid M, Kawde AN, Daud M 2015: Designs, formats and applications of lateral flow assay: A literature review. J Saudi Chem Soc 19: 689-705

Sambandam R, Angamuthu R, Kanagaraj V, Kathaperumal K, Chothe SK, Nissly RH, Barry RM, Jayarao BM, Kuchipudi SV 2017: An immuno-chromatographic lateral flow assay (LFA) for rapid on-the-farm detection of classical swine fever virus (CSFV). Arch Virol 162: 3045-3050

Sanchez JA, Pierce KE, Rice JE, Wangh LJ 2004: Linear-After-The-Exponential (LATE)-PCR: An advanced method of asymmetric PCR and its uses in quantitative real-time analysis. Proc Natl Acad Sci 101: 1933-1938

Sastre P, Gallardo C, Monedero A, Ruiz T, Arias M, Sanz A, Rueda P 2016: Development of a novel lateral flow assay for detection of African swine fever in blood. BMC Vet Res 12: 206

Schallig HD, Cardoso L, Hommers M, Kroon N, Belling G, Rodrigues M, Semião-Santos SJ, Vetter H 2004: Development of a dipstick assay for detection of Leishmania-specific canine antibodies. J Clin Microbiol 42: 193-197

Schvartz G, Farnoushi Y, Berkowitz A, Edery N, Hahn S, Steinman A, Lublin A, Erster O 2020: Molecular characterization of the re-emerging West Nile virus in avian species and equids in Israel, 2018, and pathological description of the disease. Parasit Vectors 13: 528

Segal A, Wong DT 2008: Salivary diagnostics: enhancing disease detection and making medicine better. Eur J Dent Educ 12: 22-29

Segalés J, Puig M, Rodon J, Avila-Nieto C, Carrillo J, Cantero G, Terrón MT, Cruz S, Parera M, Noguera-Julián M, Izquierdo-Useros N 2020: Detection of SARS-CoV-2 in a cat owned by a COVID-19 affected patient in Spain. Proc Natl Acad Sci 117: 24790-24793

Senthilkumaran C, Yang M, Bittner H, Ambagala A, Lung O, Zimmerman J, Giménez-Lirola LG, Nfon C 2017 : Detection of genome, antigen, and antibodies in oral fluids from pigs infected with foot-and-mouth disease virus. Can J Vet Res 81: 82-90

Shalaby MA, El-Deeb A, El-Tholoth M, Hoffmann D, Czerny CP, Hufert FT, Weidmann M, Abd El Wahed A 2016: Recombinase polymerase amplification assay for rapid detection of lumpy skin disease virus. BMC Vet Res 12: 244

Sharma S, Zapatero-Rodríguez J, Estrela P, O’Kennedy R 2015: Point-of-care diagnostics in low resource settings: present status and future role of microfluidics. Biosensors 5: 577-601

Shirzadfar H, Khanahmadi M 2018: Review on structure, function and applications of microfluidic systems. Int J Biosen Bioelectron 4: 263-265

Silva SJ, Pardee K, Pena L 2020: Loop-mediated isothermal amplification (LAMP) for the diagnosis of Zika virus: a review. Viruses 12: 19

Singer JM, Plotz CM 1956: The latex fixation test: I. Application to the serologic diagnosis of rheumatoid arthritis. Am J Med 21: 888-892 
Sit TH, Brackman CJ, Ip SM, Tam KW, Law PY, To EM, Yu VY, Sims LD, Tsang DN, Chu DK, Perera RA, 2020: Infection of dogs with SARS-CoV-2. Nature 14: 1-6

Skottrup PD, Nicolaisen M, Justesen AF 2008: Towards on-site pathogen detection using antibody-based sensors. Biosens Bioelectron 24: 339-348

Sorge US, Kurnick S, Sreevatsan S 2013: Detection of Mycobacterium avium subspecies paratuberculosis in the saliva of dairy cows: a pilot study. Vet Microbiol 164: 383-386

Stella E, Mari L, Gabrieli J, Barbante C, Bertuzzo E 2020: Permafrost dynamics and the risk of anthrax transmission: a modelling study. Sci Rep 10: 16460

Stewart LD, Tort N, Meakin P, Argudo JM, Nzuma R, Reid N, Delahay RJ, Ashford R, Montgomery WI, Grant IR 2017: Development of a novel immunochromatographic lateral flow assay specific for Mycobacterium bovis cells and its application in combination with immunomagnetic separation to test badger faeces. BMC Vet Res 13: 131

Sudhakar SB, Mishra N, Kalaiyarasu S, Jhade SK, Hemadri D, Sood R, Bal GC, Nayak MK, Pradhan SK, Singh VP 2020: Lumpy skin disease (LSD) outbreaks in cattle in Odisha state, India in August 2019: Epidemiological features and molecular studies. Transbound Emerg Dis 67: 2408-2422

Sun D, Wang J, Wu R, Wang C, He X, Zheng J, Yang H 2010: Development of a novel LAMP diagnostic method for visible detection of swine Pasteurella multocida. Vet Res Commun 34: 649-657

Tasioudi KE, Antoniou SE, Iliadou P, Sachpatzidis A, Plevraki E, Agianniotaki EI, Fouki C, Mangana-Vougiouka O, Chondrokouki E, Dile C 2016: Emergence of lumpy skin disease in Greece. Transbound Emerg Dis 63: 260-265

Thompson GM, Jess S, Murchie AK 2012: A review of African horse sickness and its implications for Ireland. Ir Vet J 65: 1-8

Tu PA, Shiu JS, Lai FY, Chen YH, Shiau JW 2018: A recombinase polymerase amplification lateral flow dipstick for field diagnosis of bovine leukemia virus infection and its effectiveness compared to iiPCR and ELISA. J Antivir Antiretrovir 10: 35-42

Upadhyay L, Chaturvedi VK, Gupta PK, Sunita SC, Sumithra TG, Prusty BR, Yadav AK 2020: Development of a visible loop mediated isothermal amplification assay for rapid detection of Bacillus anthracis. Biologicals 69: $59-65$

Vashist SK 2017: Point-of-care diagnostics: recent advances and trends. Biosensors (Basel) 7: 62

Venkatesan G, Bhanuprakash V, Balamurugan V, Kumar A, Bora DP, Reveniah Y, Arya S, Madhavan A, Muthuchelvan D, Pandey AB 2016: Simple and rapid visual detection methods of orf virus by B2L gene-based loop-mediated isothermal amplification assay. Adv Anim Vet Sci 4: 152-159

Venkatesan G, Bhanuprakash V, Balamurugan V, Singh RK, Pandey AB 2012: Development of loop-mediated isothermal amplification assay for specific and rapid detection of camelpox virus in clinical samples. J Virol Methods 183: 34-39

Venkatesan G, Kushwaha A, Kumar A, Poulinlu G, Karki M, Sasikumar P 2020: Loop mediated isothermal amplification system (LAMP): A comprehensive review with special reference to veterinary medicine. J Vet Sci Med Diagn 9: 1-11

Wang H, Cong F, Zeng F, Lian Y, Liu X, Luo M, Guo P, Ma J 2018a: Development of a real time reverse transcription loop-mediated isothermal amplification method (RT-LAMP) for detection of a novel swine acute diarrhea syndrome coronavirus (SADS-CoV). J Virol Methods 260: 45-48

Wang HM, Zhao GM, Hou PL, Yu L, He CQ, He HB 2018b: Rapid detection of foot-and-mouth disease virus using reverse transcription recombinase polymerase amplification combined with a lateral flow dipstick. J Virol Methods 261: 46-50

Wang JC, Yuan WZ, Han QA, Wang JF, Liu LB 2017: Reverse transcription recombinase polymerase amplification assay for the rapid detection of type 2 porcine reproductive and respiratory syndrome virus. J Virol Methods 243: $55-60$

Wang K, Shao H, Pei Z, Hu G 2015: Rapid detection of contagious ecthyma by loop-mediated isothermal amplification and epidemiology in Jilin Province China. J Vet Sci 15: 0340

Wang X, Bailey ES, Qi X, Yu H, Bao C, Gray GC 2020: Bioaerosol sampling at a live animal market in Kunshan (China): A noninvasive approach for detecting emergent viruses. Open Forum Infect 7: ofaa134

Wang Z, Yang PP, Zhang YH, Tian KY, Bian CZ, Zhao J 2019: Development of a reverse transcription recombinase polymerase amplification combined with lateral-flow dipstick assay for avian influenza H9N2 HA gene detection. Transbound. Emerg Dis 66: 546-551

Yang Y, Qin X, Zhang X, Zhao Z, Zhang W, Zhu X, Cong G, Li Y, Zhang Z 2017a: Development of real-time and lateral flow dipstick recombinase polymerase amplification assays for rapid detection of goatpox virus and sheeppox virus. Virol J 14: 1-8

Yang Y, Qin X, Sun Y, Cong G, Li Y, Zhang Z 2017b: Development of isothermal recombinase polymerase amplification assay for rapid detection of porcine circovirus type 2. Biomed Res Int 8403642: 1-8

Yang Y, Qin X, Song Y, Zhang W, Hu G, Dou Y, Li Y, Zhang Z 2017c: Development of real-time and lateral flow strip reverse transcription recombinase polymerase Amplification assays for rapid detection of peste des petits ruminants virus. Virol J 14: 1-10

Yang Z, Xu G, Reboud J, Ali SA, Kaur G, McGiven J, Boby N, Gupta PK, Chaudhuri P, Cooper JM 2018: Rapid veterinary diagnosis of bovine reproductive infectious diseases from semen using paper-origami DNA microfluidics. ACS sensors 3: 403-409 
Yoo H, Shin J, Sim J, Cho H, Hong S 2020: Reusable surface plasmon resonance biosensor chip for the detection of H1N1 influenza virus. Biosens Bioelectron 168: 112561

Yu X, Shi L, Lv X, Yao W, Cao M, Yu H, Wang X, Zheng S 2015: Development of a real-time reverse transcription loop-mediated isothermal amplification method for the rapid detection of porcine epidemic diarrhea virus. Virol J 12: 1-8

Zemanova MA 2019: Poor implementation of non-invasive sampling in wildlife genetics studies. Rethinking Ecology 4: 119

Zhang F, Ye Y, Song D, Guo N, Peng Q, Li A, Zhou X, Chen Y, Zhang M, Huang D, Tang Y 2017: A simple and rapid identification method for newly emerged porcine Deltacoronavirus with loop-mediated isothermal amplification. Biol Res 50: 1-7

Zhang J, Kelly P, Li J, Xu C, Wang C 2015: Molecular detection of Theileria spp. in livestock on five Caribbean islands. BioMed Res Int 2015: 624728

Zhang J, Zhang GH, Yang L, Huang R, Zhang Y, Jia K, Yuan W, Li SJ 2011: Development of a loop-mediated isothermal amplification assay for the detection of Mycobacterium bovis. Vet J 187: 393-396

Zhang JX, Hoshino K 2018: Molecular sensors and nanodevices: principles, designs and applications in biomedical engineering. Academic Press, Cambridge, $600 \mathrm{p}$.

Zhang X, Li Y, Xiao S, Yang X, Chen X, Wu P, Song J, Ma Z, Cai Z, Jiang M, Zhang Y 2019: High-frequency mutation and recombination are responsible for the emergence of novel porcine reproductive and respiratory syndrome virus in northwest China. Arch Virol 164: 2725-2733

Zhao G, He H, Wang H 2019: Use of a recombinase polymerase amplification commercial kit for rapid visual detection of Pasteurella multocida. BMC Vet Res 15: 154

Zhao G, Hou P, Huan Y, He C, Wang H, He H 2018: Development of a recombinase polymerase amplification combined with a lateral flow dipstick assay for rapid detection of the Mycoplasma bovis. BMC Vet Res 14: 412

Zheng S, Wu X, Shi J, Peng Z, Gao M, Xin C, Liu Y, Wang S, Xu S, Han H, Yu J 2018: Rapid specific and visible detection of porcine circovirus type 3 using loop-mediated isothermal amplification (LAMP). Transbound Emerg Dis 65: 597-601

Zhou J, Wu J, Zeng X, Huang G, Zou L, Song Y, Gopinath D, Zhang X, Kang M, Lin J, Cowling BJ 2016: Isolation of H5N6, H7N9 and H9N2 avian influenza A viruses from air sampled at live poultry markets in China, 2014 and 2015. Euro Surveill 21: 30331 
Plate III

Bora M. et al.: Point ... pp. 017-034

(a)

Anti PPRV mab

(Primary biomolecule)

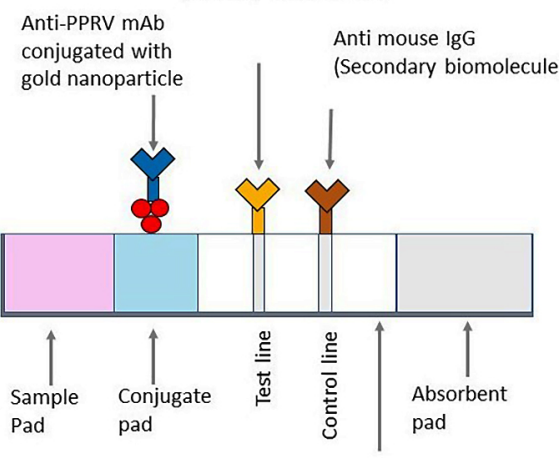

Nitrocellulose membrane
Virus-gold conjugate

complex captured by antiPPRV mAb developing the test line

\section{(b)}

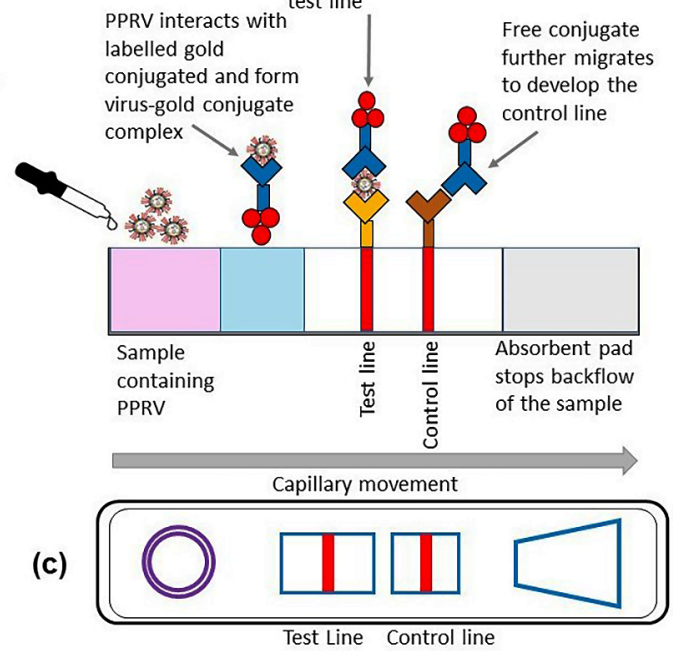

Fig. 1. (a) Schematic representation of a sandwich immunochromatographic or antigen-lateral flow assay citing Peste-des-petits ruminants virus (PPRV) as an example. (b) Sample containing PPRV is added to the sample pad and flows to the conjugate pad where it combines with anti PPRV mAb conjugated with gold nanoparticle and forms virus-conjugate complex. The complex is carried by capillary flow along the nitrocellulose membrane to the test line, where the virus become sandwiched between labelled conjugate and primary antibody (anti-PPRV $\mathrm{mAb}$ ) forming conjugate-virus-primary antibody complex forming a reddish-purple line on the test line indicating the presence of PPRV. The remaining conjugates are carried further along the strip until they come to the control line, where they are bound by secondary antibody (anti-mouse $\operatorname{IgG}$ ) creating another colour reaction indicative of proper liquid flow through the strip. Negative results are indicated by a single-coloured band in the control line (c) Representation of an immunochromatographic strip inside a plastic cassette.

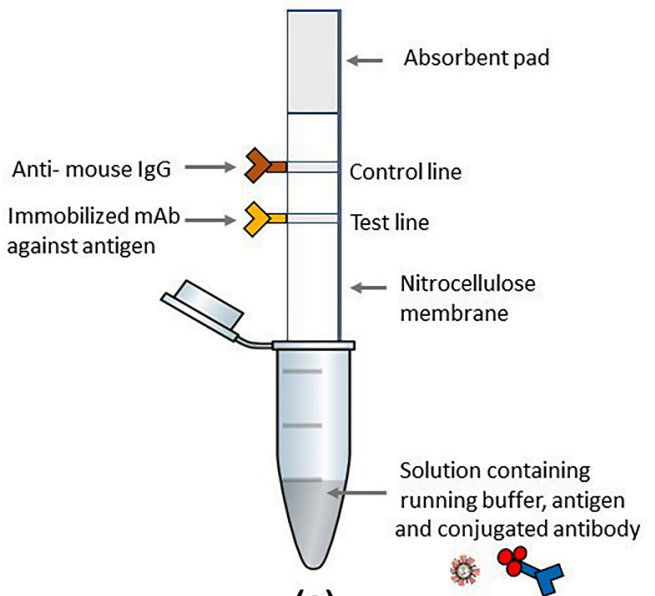

(a)

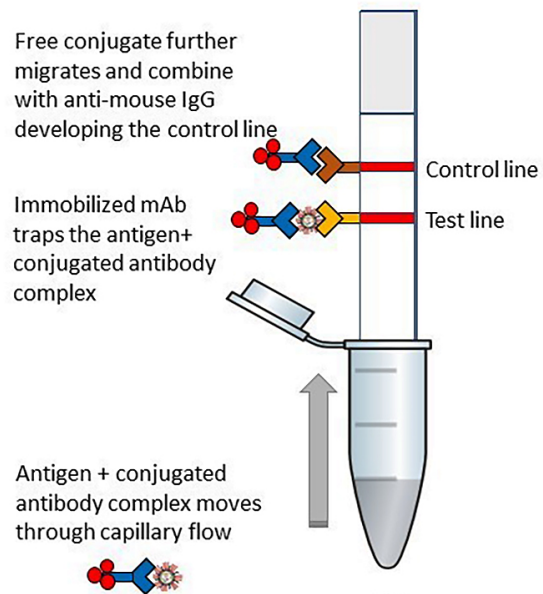

(b)

Fig 2. Basic structure of dipstick assay. (a) A dipstick placed into an Eppendorf tube containing running buffer, sample, and conjugated antibody. (b) Antigen specific to conjugated antibody combines and the complex wicks through a nitrocellulose strip which has immobilized antibodies mAb that capture the complex, providing the readout. 
Plate IV

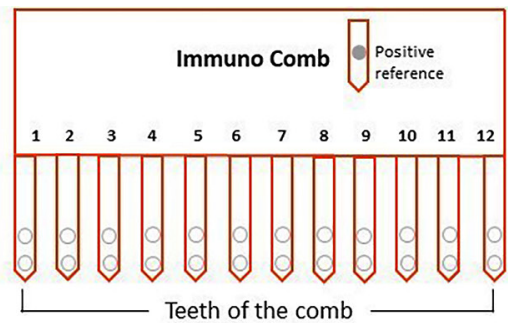

Teeth of the comb

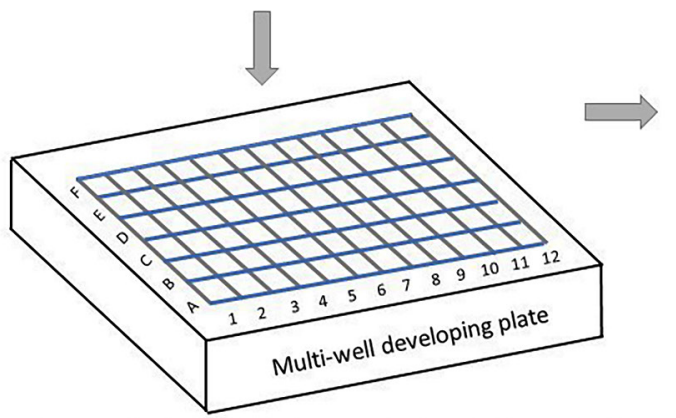

The samples to be tested are mixed with diluent in the multichamber developing plate. The test spots on the comb are then incubated with the samples in the developing plate. Specific antibodies from the samples, if present, bind to the antigens at the test spots

Fig 3. Schematic representation of immunocomb assay for detection of antibodies specific to targeted antigen. 